\title{
Balancing the Dual Mandate of Conservation and Visitor Use at a Canadian World Heritage Site in an Era of Rapid Climate Change
}

\author{
Melissa Weber ${ }^{\mathrm{a} *}$, Mark Groulx ${ }^{\mathrm{b}}$, Christopher J. Lemieux ${ }^{\mathrm{c}}$, Daniel Scott ${ }^{\mathrm{d}}$ \\ and Jackie Dawson ${ }^{\mathrm{a}}$
}

${ }^{a}$ Department of Geography, Environment and Geomatics, University of Ottawa, Ottawa, Canada; ${ }^{b}$ School of Environmental Planning, University of Northern British Columbia, Prince George, Canada; ${ }^{c}$ Department of Geography and Environmental Studies, Wilfrid Laurier University, Waterloo, Canada; ${ }^{d}$ Geography and Environmental Management, University of Waterloo, Waterloo, Canada.

Simard Hall, office 0021B, 60 University, Ottawa, ON, Canada, K1N 6N5 mwebe093@uottawa.ca, https://orcid.org/0000-0001-5916-0656

Melissa Weber is a PhD student at the University of Ottawa in the Department of Geography, Environment and Geomatics.

Mark Groulx is an Assistant Professor in the University of Northern British Columbia's School of Environmental Planning.

Christopher Lemieux is an Assistant Professor at Wilfrid Laurier University in Geography and Environmental Studies.

Daniel Scott is a professor at the University of Waterloo in the Department of Geography and Environmental Management, University Research Chair and Director, Master of Climate Change Program.

Jackie Dawson is an Associate Professor at the University of Ottawa in the Department of Geography, Environment and Geomatics and holder of the Canada Research Chair in Environment, Society and Policy.

Acknowledgements

The authors would like to acknowledge Sarah Brown and Rebecca Hasdell for their contributions to the project.

Funding

This research was supported by the Social Science and Humanities Research Council of Canada under [grant number 430-2012-0441] and by a Wilfrid Laurier University short-term research grant.

Published in Journal of Sustainable Tourism

https://doi.org/10.1080/09669582.2019.1620754 


\begin{abstract}
National parks in Canada operate under the dual mandate of conservation and visitor use, which involves balancing ecological integrity and nature-based tourism activities. Climate-induced environmental change may increase the existing tension between conservation and visitor use as major tourism resources located in protected areas are projected to undergo large-scale changes. This study draws upon the behavioural approach, scenario planning, and landscape visualizations to examine the relationship between climate change impacts, visitor perceptions, and visitor experience management at the Athabasca Glacier in Jasper National Park, Canada. Four tourism development scenarios defined by two management drivers (ecological integrity and visitor demand) with corresponding storylines and visualizations were developed for 2050. The visualized scenarios were presented to visitors $(n=304)$ in a survey to understand potential implications on visitor satisfaction. The results suggest that park managers need to find a balance between ecological integrity and visitor use in a way that ensures commercialized tourism development is limited, educational material is prioritized, and ecological integrity is maintained. While understanding the behaviour of future tourists is complex, it is a critical component of climate change adaptation planning and decision-making processes that needs to be prioritized by policymakers and protected areas managers.
\end{abstract}

Keywords: climate change, visitor experiences, visitor management, protected areas, scenario planning, visualizations, tourism 


\section{Introduction}

The core mandate of many of Canada's Protected Areas (PAs) is the maintenance and/or enhancement of ecological integrity (Environment and Climate Change Canada, 2016). By way of this policy objective, PAs form a central element in biodiversity conservation in Canada (Convention on Biological Diversity, 2018), while also meeting demands for nature-based tourism. Balancing these factors involves pursuing the mandate to protect ecological integrity against a backdrop where PAs are increasingly called upon to act as a repository of shared cultural values, and a catalyst to local/regional tourism development (McCool \& Eagles, 2015; Newsome et al., 2013). This tension describes the dual mandate of conservation and visitor use (Tonge \& Moore, 2007).

While PAs face a host of internal barriers in meeting their mandate to promote ecological integrity (e.g., limited management capacity, see Lemieux et al. 2018a and Office of the Auditor General of Canada, 2013), they also operate within a set of nested socio-ecological systems that connect local (e.g., habitat loss), regional (e.g., landscape fragmentation), and global (e.g., climate change) external stressors. Of these, climate change is particularly cross-cutting, as impacts can threaten ecological integrity and can also alter the physical and natural resource base upon which visitor experiences are developed (Scott et al., 2007; Lemieux et al., 2011a). In many mountain regions, for example, climate stressors have produced growing concern about glacial retreat, and by extension the long-term viability of glacial tourism. The human-induced change of these iconic landscapes presents a great irony, as these are often the very resources the PAs were initially designed to protect (Lemieux, 2016), and their decline is likely to affect the quality of the visitor experience, perceived destination attractiveness, and/or the motivations that underpin particular recreation activities (Scott et al., 2007; Stewart et 
al., 2016). Despite possible large-scale disruptions, the link between climate change, PA management, tourist perceptions, and visitor experience remain underexplored (Gössling et al., 2012; Scott et al., 2012a). To address this gap, this study had three related objectives:

(1) understand how the current visitor experience could be affected by climate change;

(2) identify the relationship between the current visitor experience and the four tourism development scenarios for 2050 that consider a) climate change impacts, b) visitor response/demand, and c) potential adaptation pathways; and,

(3) illustrate the ecological, social, and managerial factors that influence overall visitor satisfaction.

The study draws upon the behavioural approach, scenario planning, and landscape visualizations to examine the relationship between climate change impacts, visitor experiences, and PA management. This research extends past work on climate change and glacial tourism (see Groulx et al., 2017 and Stewart et al., 2016) by: 1) developing and visualizing scenarios depicting climate-induced change with different adaptation pathways for an international glacier tourism destination and World Heritage Site; and 2) using these visualized scenarios to gauge implications of long-term environmental change for visitor satisfaction.

Groulx et al. (2017) visualized "climate futurescapes" to assess how climate change impacts and a small set of adaptation options (e.g., the addition of safety barriers) at the Athabasca Glacier influenced visitors' perceptions of environmental change. This study builds on the baseline impact scenario developed by Groulx et al. (2017), and extends this work in two key ways. First, using an independent randomized sample of visitors, the present study applies scenario planning to develop four distinct 
and plausible adaptation pathways to systematically examine adaptation trade-offs in terms of preserving ecological integrity and visitor experiences (Gössling et al., 2012; Jopp et al., 2015). Second, these new robust visualized scenarios are integrated into a visitor survey developed following the behavioural approach. This instrument offers a structured way to examine impacts of environmental change and management decisions on one of the most common measures of visitor experience (i.e., visitor satisfaction).

As a whole, our approach helps address a direct need to examine the social license of differing adaptation pathways that could be adopted by managers working in protected glacial landscapes (Welling et al., 2015; Stewart et al., 2016), enabling PA managers to better predict future behaviour and potential support or opposition toward management decisions (Needham et al., 2016b).

\section{Literature Review}

\section{Glacier Tourism}

Glacier environments are extremely dynamic and sensitive to climate change, and are considered among the most visible and reliable indicators of climatic trends (IPCC, 2013). Since the end of the 1970s, rates of retreat, thinning, and volume loss of glaciers around the world has increased, and will continue to increase (Tennant \& Menounos, 2013). Between 2003 and 2009, 80\% of the total ice loss came from glaciers in Alaska, the Canadian Arctic, the periphery of the Greenland ice sheet, the Southern Andes, and the Asian Mountains (IPCC, 2013). Impacts at specific sites also punctuate the growing concern for glacial decline. For example, Glacier National Park in Montana lost 115 of its 150 glaciers over the past century, and scientists estimate that the remaining 35 glaciers will disappear over the next 30 years (Hall \& Farge, 2003). Similarly, the Forni Glacier in Italy has lost $36.2 \%$ of its volume and retreated by approximately two kilometres between the end of the little ice age ( 1860) and 2007 (Garavaglia et al., 
2012). In Norway, 27 out of 31 glaciers were in the process of retreat in 2010 (Furunes \& Mykletun, 2012), and glacial areas in China (Yulong Snow Mountain) and New Zealand (Franz Joseph and Fox Glaciers) show a similar pattern of retreat (Purdie et al., 2015; Wang et al., 2010).

In addition to serving as a marker of climate change, glaciers and glacial environments are the centrepiece of several World Heritage sites and national parks, with such sites capable of attracting millions of tourists each year (Welling et al., 2015). Popular glacial tourist destinations include: the Athabasca Glacier (Jasper National Park, Canada); Perito Moreno Glacier (Los Glaceir National Park, Argentina); Pastoruri Glacier (Huascarán National Park, Peru); Franz Josef and Fox Glacier (Westland Tai Putini National Park, New Zealand); Sermeq Kujalleq Glacier (Ilulissat Icefjord, Greenland); Brikdals glacier (Jostedal Glacier National Park, Norway); and Vatnajökull Glacier (Vatnajökull National Park, Iceland). These and other glacier destinations support a host of tourist activities, including commercial tours, glacier hiking/walking, hiking, educational exhibitions, ice-climbing, ice cave tours, glacier boat tours, helihiking, skiing, dogsled tours, cruise ships, glacier lake kayaking/boating, and snowmobiling (see Lui et al., 2006; Welling et al., 2015).

Glacier tourism activities like those just described often operate in highly fragile, often inaccessible, environments that require specific infrastructure that can have additional negative impacts on environmental quality and aesthetic value (Welling et al., 2015). Such infrastructures will increasingly be a response to climate-driven environmental change, which can in and of itself be a detriment to the visitor experience at glacier tourism destinations. Using photorealistic environmental visualizations, Groulx et al. (2017) examined the potential influence of climate-driven environmental change on visitor perceptions and found that impacts could diminish the sites appeal as 
a tourist attraction, with $22.9 \%$ of visitors stating they would likely not have made their current trip if site conditions reflected those depicted in a 2050 climate change scenario. Stewart et al. (2016) also investigated visitors' experiences and stakeholder perspectives of climate-related changes on tourism at the glaciers in Westland Tai Poutini National Park (Fox Glacier and Franz Josef Glaciers). They found that $46 \%$ of visitors would not visit the region if there was a possibility of not seeing the glaciers, while Wang et al. (2010) found that $80 \%$ of tourists to Yulong Mountain were motivated to see and enjoy the Baishui Glacier. If glaciers were to disappear in this region, Yuan et al. (2006) argue the appeal to tourists would be impaired, the number of tourists would decline, and tourism development would be unfavorably influenced. Wang \& Jiao (2012) recommend that glacier sites should have a museum to display glacier landscapes (past, present and future) and glacier information that encourages education and raises awareness of the need for environmental protection.

The retreat of glaciers worldwide provides compelling visual evidence of climate-induced environmental change and has been identified by tourists as a reason to not visit protected areas in the future (Gössling et al., 2012; Yuan et al., 2006). While the "last chance tourism" phenomena suggests visitation could surge in the short term as visitors' flock to experience known glacial sites before they disappear (Lemiuex et al., 2018 b), over the long-term research suggests that the loss of glaciers will diminish the landscape quality and tourism resources of current glacial destinations, negatively influencing visitor experience and visitation.

\section{Climate Change and the Dual Mandate of Protected Areas}

Within the dual mandate, it is recognized that nature-based tourism can foster support for conservation by providing revenue and opportunities for environmental education. For example, 89 percent of Canadians participate in nature-based activities 
annually (Canadian Council of Resource Ministers, 2014), and national parks, national historic sites, and marine protected areas contribute an estimated three billion dollars to the national gross domestic product (GDP) (Canadian Parks Council, 2011). The dual mandate also illustrates the significant diversity of values that PAs hold (e.g. ecological, aesthetic, spiritual) (Bushnell \& McCool, 2007), and the complexity that PA managers face in managing visitor use in a way that protects park resources (e.g. ecological integrity and biodiversity), provides satisfactory visitor experiences, and builds a constituency of park supporters (Needham et al., 2016b). Over-investment in the visitor experience is a threat in part because growth in visitation can increase direct local stressors on ecological systems and cultural heritage. High visitor numbers may stress local services (e.g. congestion at local stores or traffic), damage the landscape (e.g. trails and vegetation) or result in increased human-wildlife interactions (e.g. road incidents, animals become less wary of humans and food dependency) (Rollins et al., 2016).

Although visitor use and related activities remain a central threat to ecological integrity, climate change has emerged as one of the greatest threats to the maintenance of the ecological integrity of protected areas (Parks Canada, 2016; Wright, 2016). Operating in tandem with other stressors, climate-induced environmental change will influence the composition, structure and function of ecosystems within PA boundaries (e.g. phonological and genetic responses, range shifts, changes in the interactions between species, and species extirpations and extinctions) (Lemieux et al., 2011a). Ecological impacts from climate change will also have spill over socio-cultural effects, and the implications for tourism stem from both direct impacts (e.g. changes in temperature) and indirect impacts (e.g. degradation of landscape aesthetics) (Scott et al., 2012b). Visitors explicitly seek out desirable weather conditions, as well as the related 
physical resources that enable particular activities, meaning climate can directly influence visitor satisfaction and visitation levels (Jones \& Scott, 2006a, 2006b; Scott \& Lemieux, 2010). There is, for example, a strong correlation between visitation and temperature in US national parks (Fisichelli et al., 2015), and Jones \& Scott (2006a, 2006b) suggest that future climate trends will drive increased visitation to Canada's PAs by extending the warm weather period that visitors to PAs find desirable. While longer warm periods may drive greater visitation to PAs in Canada as a whole, a study specific to Waterton Lakes National Park found that long-term environmental changes may diminish the attractiveness of the park's landscape, offsetting some of the potential visitation gains (Scott et al., 2007). Likewise, as stated above, glacier tourism research has shown that visitation may be sensitive to site specific changes (Groulx et al., 2017; Stewart et al., 2016). Given the complexity of visitor responses to environmental change, the following section discusses the behavioural approach as one tool to enhance understandings of visitor experiences and perceptions.

\section{Accounting for Perceptions of Change}

The behavioural approach proposes that people have a multitude of motivations and/or expectations, and behave in a manner that they believe will lead to a desired goal or satisfactory experience (Manning, 1999). Within this context, motivations are defined as the reasons or forces that push people to visit an area or engage in certain behaviours or activities (Manfredo et al., 1996; Mannell, 1999; Wang \& Walker, 2010). In the tourism literature, it is noted that motivations are often influenced by three key factors: finances (e.g., income and discretionary wealth, travel costs), utilitarian considerations (e.g., travel time, perceived safety, destination infrastructure, destination services), and identity (e.g., destination uniqueness and authenticity) (Gössling et al., 2012; Hall, 2005). Importantly, motivations for travel are neither wholly about the traveller nor the 
destination, but the fit between the two at a given point in time. As such, if a visitor has selected a destination, it has likely met the motivational demands across the above criteria (Gössling et al., 2012).

From a climate change perspective, the greatest uncertainty in understanding visitor decision-making and behaviour may lie in tourists' perception of climateinduced environmental change, and whether such changes will support or undercut important motivations (Gössling et al., 2012). Climate change impacts will be an important driver in geographic and seasonal shifts in the tourism resources PAs offer (Gössling et al., 2012), but understandings of how visitor decision-making may change in response to these shifts should not assume that PAs are passive recipients of environmental change. PAs are increasingly managed with the understanding that adaptation to change is a necessary part of making future infrastructure, service, and visitor experience choices, and that adaptations undertaken in such contexts involve multiple components that are specific to a destination's environment, climate, and tourism products (Lemieux et al., 2011b; IUCN, 2018). Due to the complexity of tourism and its interdependence with other sectors, implementing adaptations can be difficult, and decisions about how to adapt can affect visitor expectations and satisfaction in the same fashion as climate-induced environmental change (Csete \& Szecsi, 2015; Jopp et al., 2015).

Within the behavioural approach, environmental change or adaptation to change would impact expectations by limiting tourists' ability to meet their desires or wants through the services they feel a PA should offer (Cohen et al., 2014). Expectations are typically based on familiarity and previous experience (Manning, 2011), but are also moulded by destination marketing and product promotions (Gössling et al., 2012). Importantly, Groulx et al. (2017) showed that when future environmental conditions, 
including a limited number of adaptations to climate impacts, fail to meet expectations, visitors may withdraw their support for a destination by simply substituting travel to another.

Further investigation into the underlying visitor and destination factors that shape preferences for adaptation pathways can facilitate a more holistic understanding of how PAs and other nature-based tourism destinations might make robust management decisions in the face of climate change (Gössling et al., 2012; Jopp et al., 2015; Welling et al., 2015). Arguably, this requires greater attention to how adaptation pathways may influence visitor satisfaction, defined as "the degree to which one is content or pleased with his or her general leisure experiences" (Beard \& Ragheb, 1980, p. 22). Examining the congruence between expectations, motivations and outcomes (i.e., visitor satisfaction) is, in fact, one of the most common ways to evaluate recreation quality, in part because satisfaction is a robust construct that captures multiple aspects of the tourism experience (e.g., environmental conditions, use level, facility development, etc.) (Manning, 2011; Needham et al., 2016b). Despite its widespread application as an indicator, there is still a need to further understand what influences satisfaction, particularly as environmental conditions and management responses in PAs evolve in response to climate change. The following section discusses the application of visualized management scenarios as a means to explore the influences of different adaptation pathways on visitor satisfaction.

\section{Methods}

\section{Study Area}

Jasper National Park (JNP) is located in Alberta, Canada within the Canadian Rocky Mountain World Heritage Site (Figure 1). It is the largest national park in the Rocky Mountains and hosted 2.3 million visitors in 2016-17 (Parks Canada, 2018a). 
The seven mountain parks (Banff, Jasper, Kootenay, Glacier, Mount Revelstoke, Waterton Lakes and Yoho) accounted for 58\% of all visitation to Canadian national parks during 2016-17, with Banff and Jasper hosting 26\% and 15\% of all visitors within national parks respectively.

Parks Canada operates under a dual mandate that states: "on behalf of the people of Canada, we protect and present nationally significant examples of Canada's natural and cultural heritage and foster public understanding, appreciation and enjoyment in ways that ensure their ecological and commemorative integrity for present and future generations” (Parks Canada, 2018c). Similarly, Jasper National Park's management plan seeks to deliver Parks Canada's mandate for resource protection, visitor experience and public appreciation and understanding (Parks Canada, 2010). As such, management goals for the Athabasca Glacier aim to protect the natural and ecological integrity of the site, while facilitating memorable experiences (Parks Canada, 2010). In recent years this balance has been challenged by increased pressure for commercial development and diversification of tourism products in JNP (e.g. development of the Glacier Skywalk near the Athabasca Glacier, proposed accommodations at Maligne Lake, and proposed Icefields Parkway bike trail). The pressure for commercial development is due to JNP's close proximity to Banff National Park, picturesque scenery, and increasing visitation, as well as the looming implications of climate-induced environmental change, signifying the ongoing tension between conservation and visitor use in Canada's national parks.

A small proportion of visitors (33\%) to JNP are from Canada, with most hailing from Alberta (52\%), Ontario (16\%) and British Columbia (10\%) (Parks Canada, $2018 b)$. The majority of international visitors are from Europe (32\%), United States 
$(16 \%)$, Asia (9\%) and Australia (6\%). Most visitors are travelling with someone or their family, with commercial groups representing 16\% of visitors (Parks Canada, 2010).

A significant proportion of visitation to JNP is supported by the Icefields Parkway, extending from the Town of Jasper to Lake Louise. More than 1.2 million visitors travel the parkway annually (Parks Canada, 2017), and the Athabasca Glacier is a significant point of interest along the parkway, as well as the most visited glacier in North America and the most heavily used day-use area in JNP (Parks Canada, 2014). Visitors can experience the glacier by hiking the trail to the toe of the glacier $(1.8 \mathrm{~km})$ or through a paid commercial tour (e.g., IceWalk has been offering guided interpretive hikes onto the glacier since 1985 and Brewster has been operating all-terrain vehicle "Ice Explorer" tours onto the glacier since 1969).

a)

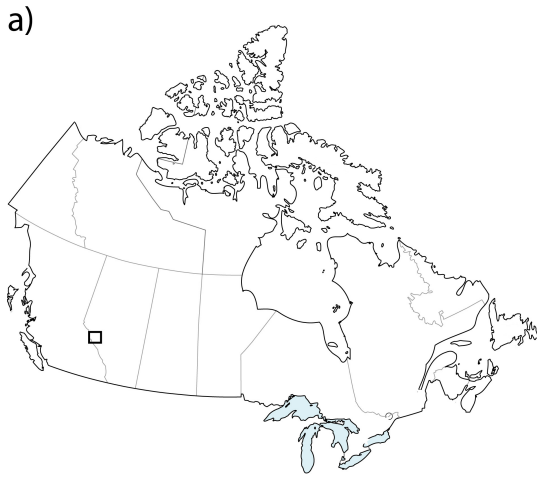

b)

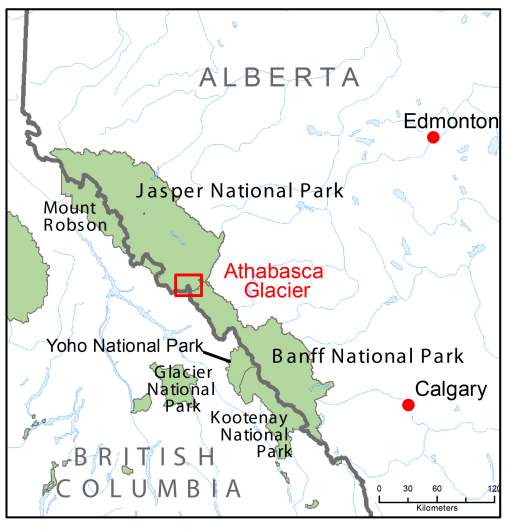

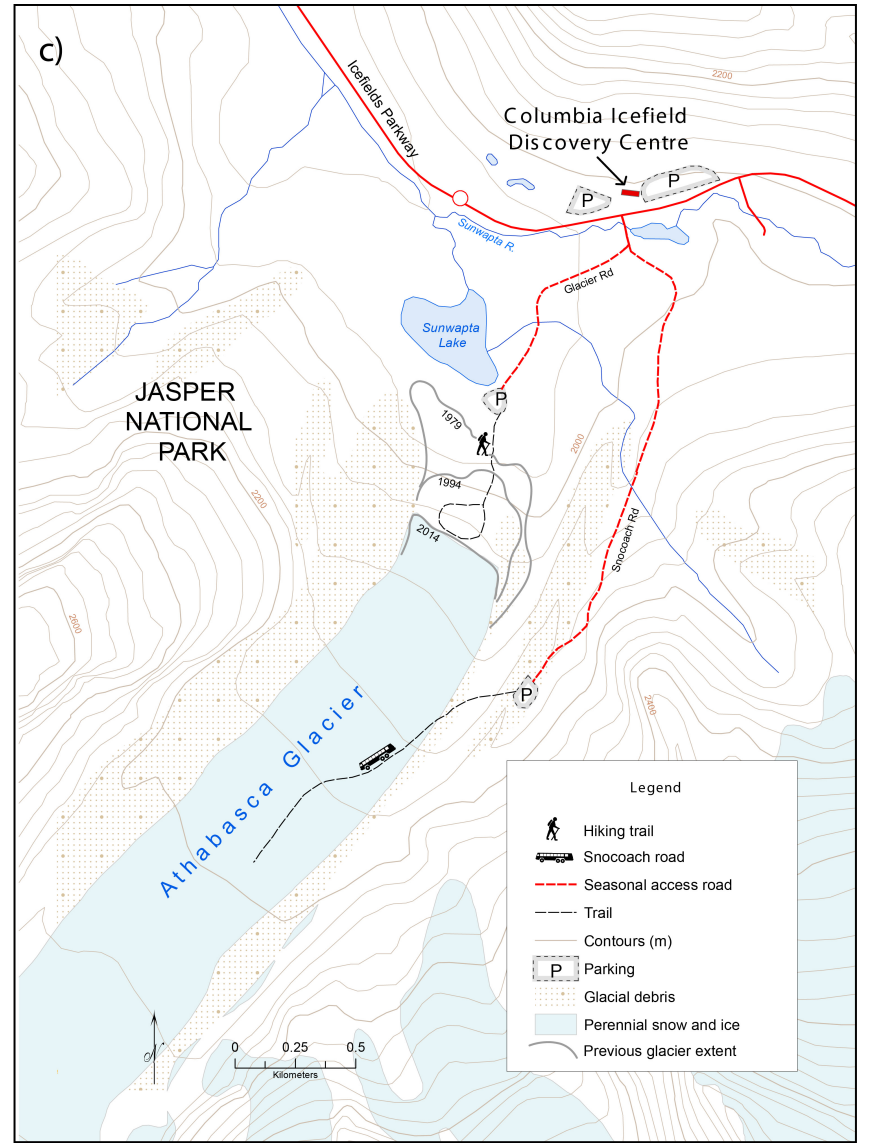

Figure 1: Maps of: (a) the location of Jasper National Park in Canada; (b) Jasper National Park; and (c) the Athabasca Glacier Site. After Groulx et al. (2017). 
While the Athabasca Glacier continues to attract visitors from around the world, it has been receding for at least the last 125 years, has lost half its volume, and has retreated more than $1.5 \mathrm{~km}$ (Parks Canada, 2014). Several aspects of the proglacial landscape have also changed, most notably the deposition of terminal moraine ridges, the development of Sunwapta lake in the early 1940s, exposure of large bedrock outcrops along the valley floor, and changes in vegetation cover (Hugenholtz et al., 2008; Luckman \& Kavanagh, 2000). More changes are inevitable as twenty-first century climate scenarios project that by 2050 , mean annual temperatures in the Canadian Columbia basin will increase by $1.8^{\circ} \mathrm{C}$ to $2.7^{\circ} \mathrm{C}$ compared to $1971-2000$ (Murdock et al., 2013). Additionally, by 2100 it is estimated that the volume of glacial ice in Western Canada will shrink by $70 \% \pm 10 \%$ relative to 2005 (Clarke et al., 2015). Alongside external development pressure linked to increasing tourism numbers and infrastructure, the IUCN (2017) has identified climate change as the most significant risk to the Canadian Rocky Mountain World Heritage Site.

\section{Scenario Planning in Support of Adaptation Thinking}

Scenario planning has been used for destination planning and decision-making in tourism (Gössling \& Scott, 2012), for anticipating the impacts of climate change through modelling, and for comparing the effectiveness and efficiency of various strategies and/or possible futures (Carlsen et al., 2013; Daconto \& Sherpa, 2010). The overall management purpose of scenario planning is to assess the long-term implications of current decisions and options, and to explore pathways of change. As Page et al. (2010) identify, tools and techniques like scenario planning are important in tourism planning and management because they allow destinations to address what needs to be done to enhance their competitiveness in the face of change. 
Similar to Carlsen et al. (2013) and Daconto \& Sherpa (2010), a bottom-up approach was used to develop four tourism management scenarios for 2050 at the Athabasca Glacier site. This involved creating a 2x2 matrix that was defined by two intersecting management drivers: 1) commitment to ecological integrity; and 2) change in visitor demand (e.g. visitation). The two scenario dimensions were selected to represent priorities of conservation and visitation that define the dual mandate. Each storyline was written to include these dimensions, and all storylines and subsequent visualizations were reviewed by tourism experts to ensure they were relevant and plausible. This approach produced a set of scenarios small enough to be interpreted (Ramirez \& Wilkinson, 2014), yet reflective of the management challenges encompassed in the dual mandate (Tonge \& Moore, 2007).

The scenario planning tool from Carlsen et al. (2013) was applied through three phases of development that drew on existing literature about glacial change, tourism and climate change, and glacial tourism. Applying this tool resulted in four detailed storylines capturing different pathways JNP management may pursue in balancing conservation and visitor use at the Athabasca Glacier site under persistent climate change (Table 1). The storylines were translated into visualized scenarios using a photomontage technique in Adobe Photoshop CS5. Similar to Groulx et al. (2017), the scenarios (storylines and visualizations) were reviewed by three tourism and climate change experts. The baseline impact scenario for 2050 developed by Groulx et al. (2017) depicting environmental landscape change (e.g., glacial mass-volume loss, snow cover change, etc.) was previously reviewed by three glaciologists and twelve tourism and climate change experts. The review by glaciologists was to ensure the type and extent of environmental changes presented for 2050 did in fact meet the standard of being a plausible future state. From this single impact state, storylines developed using 
the Carlsen et al. (2013) tool were applied to visualize four distinct, but plausible future

tourism states (Figure 2).

Table 1: Application of Scenario Planning Tool.

\section{Phase One: Framing Scenarios}

The purpose of using scenarios is threefold:

1. Identify future challenges, both opportunities and threats, related to climate change;

2. Identify options for adaptation; and

3. Assess options or combination of options for coping with the challenges of climate change that arise in different scenarios.

\begin{tabular}{|c|c|c|c|c|c|}
\hline \multicolumn{6}{|c|}{ Phase Two: Building Scenarios } \\
\hline $\begin{array}{l}\text { A) Choosing the } \\
\text { timeframe }\end{array}$ & \multicolumn{2}{|c|}{$\begin{array}{l}\text { B) Choosing a focal } \\
\text { question }\end{array}$} & \multicolumn{2}{|c|}{$\begin{array}{l}\text { C) Creating key } \\
\text { drivers and states }\end{array}$} & $\begin{array}{l}\text { D) Constructing } \\
\text { scenario narratives }\end{array}$ \\
\hline $\begin{array}{l}2050 \text { was selected } \\
\text { for this study to } \\
\text { focus on long-term } \\
\text { planning issues that } \\
\text { are associated with a } \\
\text { changing climate } \\
\text { and to ensure that } \\
\text { the scenarios show } \\
\text { real change and are } \\
\text { not just an extension } \\
\text { of the present. }\end{array}$ & $\begin{array}{l}\text { Optior } \\
\text { adapta } \\
\text { possib } \\
\text { accept } \\
\text { Asses } \\
\text { chang } \\
\text { scenar } \\
\text { will } \mathrm{m} \\
\text { negati } \\
\text { percep }\end{array}$ & $\begin{array}{l}\text { s: what } \\
\text { tions are } \\
\text { e and } \\
\text { able? } \\
\text { : what level of } \\
\text { based on the } \\
\text { os presented } \\
\text { tigate } \\
\text { e visitor } \\
\text { tions? }\end{array}$ & $\begin{array}{l}\text { Indicators: } \\
\text { Environmental } \\
\text { (natural feature } \\
\text { Social (numbe } \\
\text { people); } \\
\text { Managerial (fa } \\
\text { and infrastruct }\end{array}$ & $\begin{array}{l}\text { of } \\
\text { ilities } \\
\text { re). }\end{array}$ & $\begin{array}{l}\text { The scenarios should } \\
\text { be focused on } \\
\text { describing the } \\
\text { relationship between } \\
\text { the most important } \\
\text { key drivers. A } \\
\text { scenario is then } \\
\text { constructed by } \\
\text { choosing one state for } \\
\text { each of the prioritized } \\
\text { key drivers. }\end{array}$ \\
\hline \multicolumn{6}{|c|}{ Phase Three: Using the Scenarios } \\
\hline A) Identifying challer & \multicolumn{3}{|c|}{ B) Identify options } & \multicolumn{2}{|c|}{ C) Assess adaptation options } \\
\hline \multicolumn{2}{|c|}{$\begin{array}{l}\text { Climate-induced } \\
\text { environmental change will } \\
\text { result in changes to the } \\
\text { landscape, such as glacial } \\
\text { extent, snow cover, } \\
\text { proglacial lakes and streams, } \\
\text { and vegetation. These } \\
\text { changes could impact the } \\
\text { visitor experience and } \\
\text { present challenges for } \\
\text { stakeholders. }\end{array}$} & \multicolumn{2}{|c|}{$\begin{array}{l}\text { Adaptation options are } \\
\text { informed from the literature. } \\
\text { The proposed adaptation } \\
\text { options are: helicopter tours } \\
\text { (Stewart et al., 2016); tram } \\
\text { (Kim et al., 2014); canoe and } \\
\text { kayaking } \\
\text { (Purdie, 2013); and } \\
\text { interpretive material. }\end{array}$} & \multicolumn{2}{|c|}{$\begin{array}{l}\text { The scenarios (storylines and } \\
\text { visualizations) were validated } \\
\text { by tourism and climate } \\
\text { change experts. The } \\
\text { visualizations were then } \\
\text { assessed by visitors through a } \\
\text { survey. }\end{array}$} \\
\hline
\end{tabular}




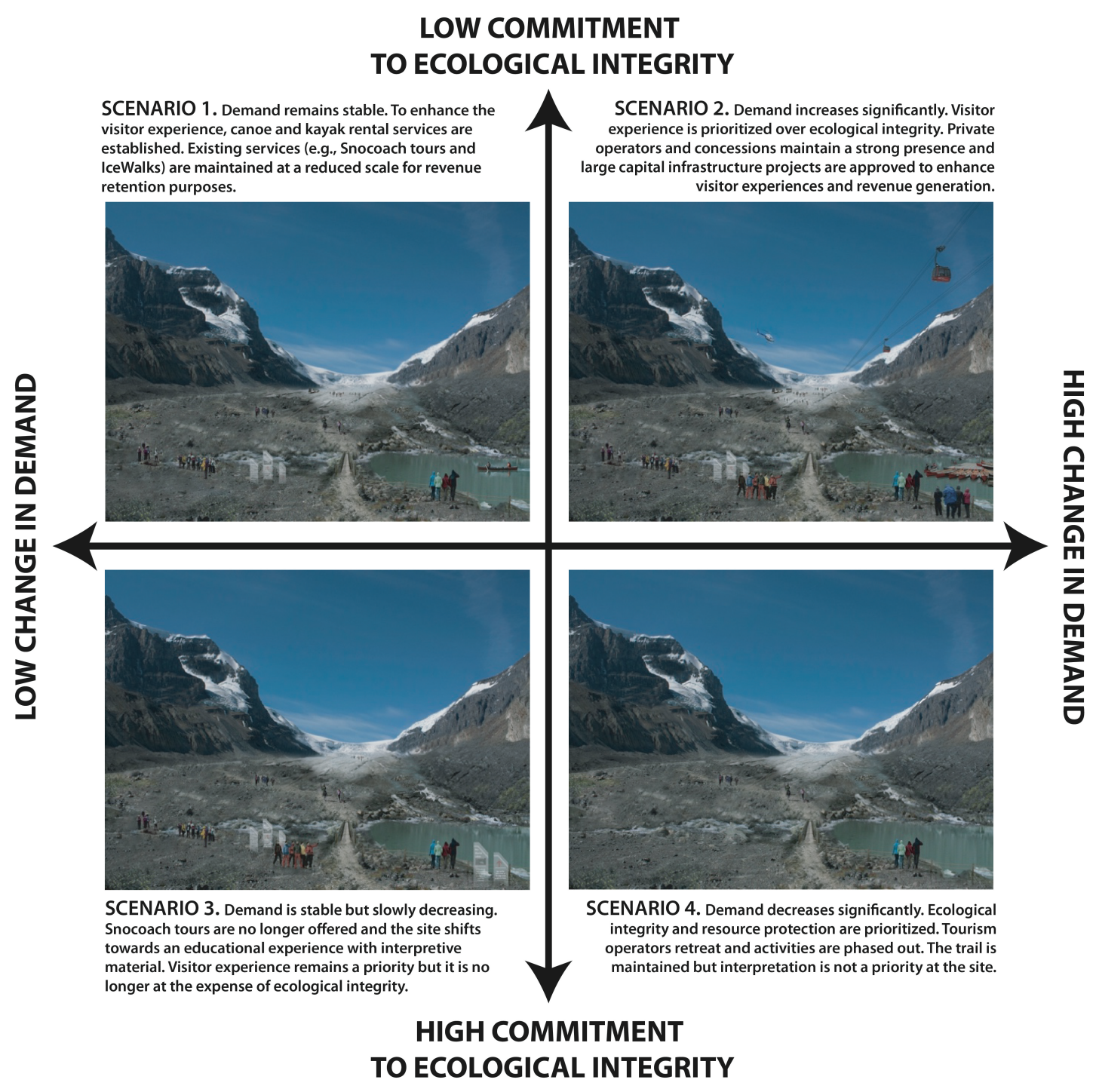

Figure 2: Visualized tourism development scenarios and storylines for 2050.

\section{Survey Design}

In support of the research objectives, a survey was designed around the evaluation of the visualized tourism development scenarios using the behavioural approach as a framework. The visualizations and corresponding labels (e.g. scenario one, scenario two, scenario three, and scenario four) were incorporated into the survey, without the continuum labels (ecological integrity and visitor demand) and corresponding storylines to reduce bias. A five-point likert scale was adopted to measure visitors' motivations, expectations, and satisfaction. Items for the motivation scale were adapted from the recreation experience preference (REP) instrument and 
previous glacial tourism research (see Groulx et al., 2017; Wilson et al., 2014; Lemieux et al., 2018b). In addition to overall satisfaction, visitors were asked to indicate how satisfied they would be with future environmental conditions (e.g., snow cover, glacier extent, proglacial lakes and streams and vegetation) and what their expectations were for social and physical site conditions that relate to their glacier viewing experience (e.g., number of people, facilities and infrastructure). To place these responses in the broader context of tourism experiences at the site, the survey included questions about the nature of each visitor's trip, potential management actions to address climate impacts in JNP, and general perceptions of climate change.

\section{Data Collection and Analysis}

Data was collected at the Athabasca Glacier site during two data collection periods in 2016 (July 26 to August 3 and August 31 to September 2) using two types of tablet computers: iPad (9.7”) and Samsung Galaxy View (18.4”). The electronic delivery of self-administered surveys generates more accurate results than those obtained with paper surveys (Gwaltney et al., 2008), tends to result in higher item response rates than paper surveys (Belisario et al., 2015), and has the added benefits of higher levels of participant enjoyment and reduced need for timely data input that is subject to human error (Groulx et al., 2017; Lemieux et al., 2016). To overcome the limitations of using tablets, such as potential screen glare and limited screen size, laminated booklets $(8.5$ " $\mathrm{x} 14$ ") with the visualizations were provided as supplementary material. Visitors were recruited as they were exiting the trail to the glacier using a systematic random sampling approach because it is known to be less subject to selection errors by field researchers conducting on-site surveys (Vaske, 2008). 
Descriptive statistics were produced in SPSS (v. 24) to understand visitor characteristics, general perceptions of visitor satisfaction, climate change, and proposed management actions. Inferential statistical tests, such as spearman correlations and Friedman's Anova and Wilcoxon post-hoc tests, were also produced. The spearman correlation was selected as it is a non-parametric test that is based on the ranks of the data rather than the actual values, which is appropriate for ordinal values, such as those collected using a likert scaled survey item (Vaske, 2008). To facilitate analysis of the broad suite of motivation items ( $\mathrm{n}=11)$, an exploratory factor analysis (EFA) was performed using principal axis factoring and a direct oblimin rotation (Briggs et al., 1986; Stevens, 2009).

\section{Results}

\section{Respondent Characteristics}

A total of 315 surveys were collected over the first $(n=202)$ and second $(n=113)$ data collection periods. Prior to analysis, missing data and unengaged responses were removed, leaving a final sample of 304. Participants were removed for incomplete responses $(>15 \%$ of the survey) or having a standard deviation of $<0.7$ (e.g. selecting the same answer for every question). The response rates (55\% and $44 \%$ respectively) were comparable in both cases, and broadly reflective of response rates for many studies in social science and parks, recreation, and human dimensions of natural resource research (e.g. Connelly et al., 2003; Steeh et al., 2001). The most common reasons that visitors did not participate were a lack of time (47\%) and limited proficiency with the English language (14\%). Non-participants also noted that they had family waiting, had a dog in the car, were part of a bus tour, and/or did not want to stop due to the weather. 
The sample was comprised of a slightly higher proportion of females (54\%), and included visitors 18 to 73 years in age (median age $=38$ ). Nearly half of the respondents $(48 \%)$ had an annual income above the Canadian family median $(\$ 78,000)$ (Statistics Canada, 2016), and the majority were well educated (68\% had a bachelor's degree or higher). Most visitors (68\%) were not Canadian citizens; $65 \%$ travelled from outside of Canada from nineteen different countries, most notably the United States $(n=76)$; the United Kingdom $(n=25)$ and Australia $(n=19)$. Among Canadian visitors, the most common place of residence was British Columbia $(n=35)$; Alberta $(n=32)$ and Ontario $(n=24)$. This sample appears to be consistent with visitation patterns at JNP as a whole (Parks Canada, 2010; Parks Canada, 2018b).

\section{Visitor Motivations}

In order to facilitate analysis and better understand visitor motivations, an exploratory factor analysis (EFA) was performed to reduce the eleven motivation items to a more manageable and meaningful number. After removing items below the 0.40 threshold (Stevens, 2009), six of the eleven motivation items loaded on two separate factors in the EFA. This two-factor model explains $72 \%$ of the variance in the original data. Factor one was titled learning, and included four items capturing a desire to learn, reflect, and connect to the environment ( $a$ lpha $=0.86$ ). Factor two included two items capturing a desire to share and experience the destination; this factor was titled sharing. The Spearman-Brown formula was used to estimate the reliability of the sharing factor because it only had two variables (equal length $=0.65$ and unequal length $=0.65$ ) (Eisinga et al., 2013). A value of 0.70 or 0.80 is considered acceptable for Cronbach's Alpha, but in parks, recreation and human dimensions' research, an alpha of 0.65 to 0.70 is considered adequate (Vaske, 2008). 


\section{Visitor Satisfaction}

A large proportion (91\%) of visitors were either satisfied or very satisfied with their overall experience at the Athabasca Glacier site. However, when examining the various elements within the visitor experience, there was far less consensus among visitors and focused satisfaction ratings were lower (Table 2). With regard to their current trip, visitors were most satisfied with the proglacial lakes and streams $(66 \%)$ and the facilities and infrastructure (64\%), and were least satisfied with the number of people present (44\%) and the state of the vegetation (48\%).

Table 2: Percent of satisfied and very satisfied visitors with the current visitor experience and 2050 tourism development scenarios.

\begin{tabular}{|c|c|c|}
\hline & $\begin{array}{l}\text { Satisfied or Very } \\
\text { Satisfied }(\%)\end{array}$ & Median \\
\hline \multicolumn{3}{|l|}{ Environmental } \\
\hline \multicolumn{3}{|l|}{ Current Visitor Experience } \\
\hline Snow cover & 51 & 4 \\
\hline Glacier extent & 55 & 4 \\
\hline Proglacial lakes & 66 & 4 \\
\hline Vegetation & 48 & 3 \\
\hline \multicolumn{3}{|l|}{ Projected Visitor Experience } \\
\hline Snow cover & 30 & 3 \\
\hline Glacier extent & 29 & 3 \\
\hline Proglacial lakes & 44 & 3 \\
\hline Vegetation & 33 & 3 \\
\hline \multicolumn{3}{|l|}{ Social } \\
\hline \multicolumn{3}{|c|}{ Number of People Encountered } \\
\hline Current visitor experience & 44 & 3 \\
\hline Scenario one & 40 & 3 \\
\hline Scenario two & 14 & 2 \\
\hline Scenario three & 41 & 3 \\
\hline Scenario four & 75 & 4 \\
\hline \multicolumn{3}{|l|}{ Managerial } \\
\hline \multicolumn{3}{|l|}{ Facilities and Infrastructure } \\
\hline Current visitor experience & 64 & 4 \\
\hline Scenario one & 48 & 3 \\
\hline Scenario two & 19 & 2 \\
\hline Scenario three & 51 & 4 \\
\hline Scenario four & 65 & 4 \\
\hline \multicolumn{3}{|l|}{ Overall Visitor Experience } \\
\hline Current visitor experience & 91 & 4 \\
\hline Scenario one & 47 & 3 \\
\hline Scenario two & 16 & 2 \\
\hline Scenario three & 50 & 3 \\
\hline Scenario four & 74 & 4 \\
\hline
\end{tabular}

Note: measured on a five-point Likert scale $(1=$ very unacceptable; $5=$ very acceptable $)$ 
Visitor satisfaction with all projected environmental landscape features (i.e. the state of features in 2050) decreased compared to satisfaction with the current experience (Table 2). Similar to the current experience, visitors indicated in the future they would be most satisfied with the proglacial lakes and streams (e.g. 44\% satisfaction for 2050 compared to $66 \%$ for the current experience). Unlike their current experience, where visitors were relatively satisfied with the glacier extent, in the future they anticipated being very unsatisfied with the projected glacier extent (29\% indicated they were satisfied or very satisfied with the extent). The number of people present in each of the tourism development scenarios also directly influenced satisfaction. For example, scenario two had the largest number of people present at the site and had the lowest overall satisfaction ranking, while scenario four had the lowest number of people present and had the highest satisfaction rating (e.g. 14\% were satisfied with number of people present in scenario two and $75 \%$ were satisfied with the number of people present in scenario four). In fact, visitors were more satisfied with the number of people in scenario four than with the number of people encountered during their current experience (e.g. $44 \%$ of visitors were satisfied with the number of people). Conversely, satisfaction with facilities and infrastructure decreased in the scenarios where more commercialized recreational activities were present. For example, scenario three and four had the highest satisfaction ratings, whereas scenario one and scenario two had the lowest satisfaction ratings and the highest amount of tourism related development.

To illustrate the link between overall satisfaction and different elements of the visitor experience (motivations, expectations and satisfaction with specific site elements) for the current experience, the behavioural approach was adopted and a spearman correlation analysis was performed (Table 3). None of the factors had what Vaske (2008) considers to be a strong correlation (i.e. when $r_{s}$ is greater than 0.70 ). 
Facilities and infrastructure had the strongest correlation with overall satisfaction $\left(\mathrm{r}_{\mathrm{s}}=\right.$ $0.394, \mathrm{p}<0.01)$, followed by snow cover $\left(\mathrm{r}_{\mathrm{s}}=0.372, \mathrm{p}<0.01\right)$ and glacier extent $\left(\mathrm{r}_{\mathrm{s}}=\right.$ $0.340, \mathrm{p}<0.01$ ). The motivation factors (learn and share) and expectation factors (number of people and facilities) correlated weakly with overall satisfaction.

Table 3: Spearman correlation for motivations, expectations, and satisfaction variables for the current experience.

\begin{tabular}{|c|c|c|c|c|c|c|c|c|c|c|c|}
\hline & 1 & 2 & 3 & 4 & 5 & 6 & 7 & 8 & 9 & 10 & 11 \\
\hline \multicolumn{12}{|l|}{ Motivation } \\
\hline 1. Learn & - & $.345 * *$ & .000 & -.026 & $.132 *$ & -.009 & .084 & $.123^{*}$ & -.011 & .103 & $.206 * *$ \\
\hline 2. Share & & - & .022 & .030 & $.118^{*}$ & $.137^{*}$ & $.172 *$ & .030 & .036 & -.094 & $.145^{*}$ \\
\hline \multicolumn{12}{|l|}{ Expectation } \\
\hline 3. Number of people & & & - & $.197 * *$ & .092 & .018 & .019 & .049 & $.244 * *$ & .038 & .035 \\
\hline 4. Facilities & & & & - & .017 & -.005 & -.065 & -.079 & .026 & $-.385 * *$ & $-.193 * *$ \\
\hline \multicolumn{12}{|l|}{ Satisfaction } \\
\hline 5. Snow cover & & & & & - & $.638 * *$ & $.461 * *$ & $.383 * *$ & $.251 * *$ & $.166^{* *}$ & $.372 * *$ \\
\hline 6. Glacier extent & & & & & & - & $.519 * *$ & $.394 * *$ & $.239 * *$ & $.126^{*}$ & $.340 * *$ \\
\hline 7. Proglacial lakes & & & & & & & - & $.572 * *$ & $.265^{* *}$ & $.223 * *$ & $.325^{* *}$ \\
\hline 8. Vegetation & & & & & & & & - & $.290 * *$ & $.262 * *$ & $.266^{* *}$ \\
\hline 9. Number of people & & & & & & & & & - & $334 * *$ & $.252 * *$ \\
\hline 10. Facilities & & & & & & & & & & - & $.394 * *$ \\
\hline $\begin{array}{l}\text { 11. Overall } \\
\text { satisfaction }\end{array}$ & & & & & & & & & & & - \\
\hline
\end{tabular}

* Correlation is significant at the 0.05 level (2-tailed).

** Correlation is significant at the 0.01 level (2-tailed).

To explore the differences in overall visitor satisfaction among visitors' current experience and the tourism development scenarios for 2050 in more detail, a Friedman's Anova with Wilcoxon post-hoc tests was performed. The Bonferroni correction was applied to compensate for error inflation, and significance was accepted only beyond a .005 level. The results show significant differences in ratings across the different scenarios, $\mathrm{X}^{2}(4)=526.40 ; p<0.000$. Wilcoxon post-hoc tests and effect size calculations also illustrate a clear relationship between the current visitor experience and the scenarios (Table 4). In all cases, the current experience was rated as significantly higher compared to all future scenarios. Likewise, amongst the differing scenarios, scenario four (highest commitment to ecological integrity) was rated significantly higher in overall satisfaction than all other scenarios, while scenario two (lowest commitment to ecological integrity) was rated significantly lower in overall 
satisfaction than all other scenarios. Visitor satisfaction with the number of people, facilities and infrastructure and overall experience for the projected tourism management scenarios coincided with each scenario's commitment to ecological integrity. As the management commitment to ecological integrity decreased, so did visitor satisfaction.

Table 4: Friedman's ANOVA and Wilcoxon post hoc tests of overall satisfaction.

\begin{tabular}{|c|c|c|c|c|c|c|c|}
\hline \multirow[t]{2}{*}{ Scale comparison } & \multirow[t]{2}{*}{$N$} & \multicolumn{3}{|c|}{ Friedman's Anova } & \multicolumn{2}{|c|}{$\begin{array}{c}\text { Wilcoxon } \\
\text { Signed-Rank }\end{array}$} & \multirow{2}{*}{$\begin{array}{c}\text { Effect } \\
\text { Size } \\
r\end{array}$} \\
\hline & & $\mathrm{d} f$ & $X_{F}^{2}$ & Sig. & $\begin{array}{c}\mathrm{Z} \\
\text { value }\end{array}$ & Sig. & \\
\hline All scales & 304 & 4 & 526.40 & 0.000 & & & \\
\hline Current - Scenario one & 304 & & & & -10.83 & .000 & -0.62 \\
\hline Current - Scenario two & 304 & & & & -13.73 & .000 & -0.79 \\
\hline Current - Scenario three & 304 & & & & -10.87 & .000 & -0.62 \\
\hline Current - Scenario four & 304 & & & & -5.92 & .000 & -0.34 \\
\hline Scenario one - Scenario two & 304 & & & & -11.17 & .000 & -0.64 \\
\hline Scenario one - Scenario three & 304 & & & & -1.60 & .109 & -0.09 \\
\hline Scenario one - Scenario four & 304 & & & & -7.44 & .000 & -0.43 \\
\hline Scenario two - Scenario three & 304 & & & & -11.49 & .000 & -0.66 \\
\hline Scenario two - Scenario four & 304 & & & & -12.02 & .000 & -0.69 \\
\hline Scenario three - Scenario four & 304 & & & & -7.96 & .000 & -0.46 \\
\hline
\end{tabular}

Note: Bonferroni correction applied and post-hoc test is significant at the 0.005 level.

\section{Perceptions of Climate Change and Proposed Management Strategies}

The majority of visitors were very sure $(79 \%)$ or somewhat sure $(13 \%)$ that climate change is happening and that climate change is caused by human activities $(39 \%)$ or the combination of human activities and natural changes (55\%). Most visitors acknowledged that they were moderately (34\%) or extremely (45\%) concerned about the issue of climate change. To help identify the social acceptability of potential adaptation management options for the site, visitors evaluated a list of potential management actions that have been proposed, suggested, or implemented at similar tourist destinations. The action of permanently closing the PA site to all visitation was considered acceptable to only a few visitors (14\% of visitors). Limiting, but not eliminating, visitation was acceptable to a notably larger proportion of visitors $(67 \%$ of visitors), while knowledge-based interventions like the development of a guided 
interpretive trail and implementation of a citizen science program were more highly favoured among the majority of visitors ( $83 \%$ and $78 \%$ of visitors respectively).

\section{Discussion}

Climate-induced environmental change and resulting impacts on socio-cultural systems are likely to complicate or enhance the existing tension between the preservation of ecological integrity and the promotion of visitor experiences in PAs (CPAWS, 2015; IUCN, 2017). At the Athabasca Glacier site specifically, although Brewster Travel Canada has been operating vehicle-based glacier tours since 1969, there is uncertainty as to how long the company is going to be able to continue operating tours due to climate change. Recently, the company proposed and received approval to build a glass-floor observation platform that opened in 2014 at a cost of more than \$21 million (Needham et al., 2016a). While the glacier skywalk is adjacent to, rather than directly at, the Athabasca glacier site, controversy around the development of this new visitor experience captures the threat that expansionist pressure for visitor experiences in PAs presents to ecological integrity. The installation of this new piece of infrastructure not only saw a public viewpoint converted into a commercial entity, but as Needham et al. (2016a) identified, the project has contributed to the broader privatization of Canada's national parks, has increased ecological impacts, and influenced a proliferation of a "theme park like" experience.

Careful attention should be paid to Needham et al.'s (2013) caution about investment in "theme park like" experiences. Beyond the obvious misalignment between heavy infrastructure development and Parks Canada's commitment to limit commercial development within protected boundaries, results from this study suggest heavy infrastructure and visitor crowding that are associated with investment in visitor 
experiences, can come at the expense of ecological integrity and ironically may in turn directly reduce visitor satisfaction. Similar concerns were noted in New Zealand where rapidly changing physical conditions at the Fox and Franz Josef Glaciers have surfaced unexpected impacts of prioritizing tourism operations over commitments to conservation. More specifically, concession allowances that permitted increased aircraft activity at the Franz Josef Glacier have led directly to diminished visitor satisfaction due to growing annoyance with over-flights in the glacier valley (Stewart et al., 2016). A tourism company has also submitted a proposal that is currently under review by the Department of Conservation for the development of a gondola for ease of viewing the rapidly receding Franz Josef Glacier, now only accessible by helicopter after the face of the glacier collapsed in 2012 (Slaughter, 2018).

As climate threatened tourism resources like glaciers diminish, political pressure may increase from local communities and tourism stakeholders to seek benefit from the natural resources in ways that are less consistent with current conservation goals. The results from this study confirm that although climate-induced environmental change will negatively impact visitor satisfaction at the Athabasca Glacier, management decisions have the potential to be just as detrimental to visitor satisfaction. Managing this threat is an important decision in the short-term, yet considerations of how to balance investment in visitor experience and with commitments to ecological integrity requires long-term thinking. Under the dual mandate, Parks Canada's responsibility is not merely to promote experiences and educational opportunities, but to do so in a manner that is sustainable for future generations.

Evidence suggests that with the current greenhouse gas emissions trajectory, the Athabasca Glacier will not exist in any form resembling its present state within a generation; but, Parks Canada and JNP will. Parks Canada will inevitably have to 
initiate the process of engaging in an era of policy and management innovation. While predicting climate change and visitor responses will be complex and uncertain, failure to integrate climate change into all stages of decision-making, development planning, and policy-making will be to the detriment of Parks Canada. Policy innovations will have to be informed by socio-economic cost-benefit analysis, stakeholder consultation, and policy adjustment to identify pathways that balance the dual mandate of conservation and visitor use. For example, Parks Canada could initiate the process of developing a public transportation strategy to alleviate traffic (and associated GHG emissions) and crowding, and to support climate change mitigation and adaptation activities on-site. However, research has repeatedly concluded that the capacity to adapt to climate change is low within the protected areas sector (see Lemieux et al. 2011b).

While climate-induced environmental change is creating significant challenges for balancing conservation against commercialization, Stewart et al. (2016) acknowledge that receding glaciers present an opportunity to educate visitors about the realities of climate change. The results of this study reveal that visitors desire an experience that reflects a pristine and natural environment, but with an educational experience weaved through this natural backdrop. Nearly half of visitors indicated that learning about glaciers (50\%) and the impact of climate change on glaciers $(52 \%)$ were important in their decision to visit the site. The desire for adaptations of a knowledge focus and the weak correlation between motivation factors (learn and share) with overall satisfaction (Table 3) could suggest that visitors were not finding the interpretive materials they hoped for. Reinforcing visitors' willingness and eagerness to learn about climate change in PAs reflects Schweizer et al.'s (2013) call to use PAs as a learning and communication platform, and the findings from this study specifically suggest that the Athabasca Glacier can be a powerful educational tool to help visitors understand 
their environmental impact and the importance of environmental protection. It is concerning that the Agency continues to invest human and financial resources in unnecessary and expensive infrastructure instead of focusing on ecological integrity monitoring and other programs related to conservation, education, and interpretation, all of which are central to the Agency's mandate.

One hundred years from now, few environments will be able to tell the story of society's struggle to address climate change as clearly and compellingly as glacial landscapes like the Athabasca Glacier. Short term development and exploitation of PA resource are not the only way to enhance visitor experience at sites like the Athabasca Glacier. Rather than experiences like the glacier skywalk, Stewart et al. (2016) suggest that broader conservation outcomes can be realized through interpretation of glacier recession scenarios that allow tourists to see and understand the effects of a changing climate at a local scale, and in an appropriate historical and sociocultural context. Their suggestion also reflects a lesson potentially already learned in Norway, where three glacier visitor centres were developed around the Jostedalen Glacier that have a focus on educating visitors about climate change (Aall \& Hoyer, 2005).

By using the link between climate change and glacial change as a window to raise awareness and curate the climate story, knowledge-based investments present flexible, long term opportunities to evolve visitor experiences along with an evolving environment. Despite the fact that interpretation is shown to both promote public understanding of environmental issues and positively influence visitor satisfaction (Ham \& Weiler, 2007; Hill et al., 2007; Hvenegaard \& Shultis, 2016), interpretive programs have a history of being negatively influenced by budget cuts and reductions in revenue (Hvenegaard \& Shultis, 2016). The changing nature of parks and PAs represents an important vehicle to inform and educate the public on climate change through visitor 
experiences that expand environmental consciousness, while remaining sensitive to the protection of ecological integrity. Parks Canada and park managers at JNP have a tremendous, if not lamentable, opportunity to use one of Canada's most iconic landscapes as an educational and documentary tool to help visitors and society alike understand their impact and the ever-present importance of environmental protection and conservation in a changing world.

\section{Conclusion}

This study addresses not only the implications of climate change for visitor experiences at one of Canada's most iconic landscapes located within a World Heritage Site, but also draws on scenario planning and landscape visualizations to examine the different pathways that adaptation can take in light of policy and management goals. From a visitor experience perspective, the results indicate that as climate-induced environmental change alters the glacial landscape, visitor satisfaction will be negatively impacted. More importantly, the results revealed that visitors are more sensitive to tourism-related development than the environmental changes resulting from climate change. These findings are in line with previous research by Groulx et al. (2017) who identified a meaningful relationship between natural experiences, aesthetic quality, and consumer behaviour at this site, but advances previous work by directly comparing the visitor satisfaction of multiple adaptation pathways within the context of Parks Canada's dual mandate.

Understanding the behaviour of future tourists is an important conceptual barrier for climate change impact and adaptation studies in the tourism sector to overcome (Scott et al., 2007). Using environmental visualizations, this study systematically linked adaptation scenarios to visitor satisfaction in an attempt to understand the future of tourism and visitor experience at the Athabasca Glacier. This approach comes with 
limitations as there is uncertainty whether the perceptions of contemporary visitors will be shared by future generations (Scott et al., 2007). It is possible that tourists may learn to accept new conditions, adjust their perceptions of acceptable conditions, or focus on a different set of activities supported by prevailing environmental conditions (Gössling et al., 2012). There is also uncertainty whether future generations, who have no frame of reference of previous conditions, would respond to changing conditions in the same manner as current visitors (Scott et al., 2007, 2008 2012a) or if degraded conditions may become the new normal (Gössling et al., 2012).

We believe this limitation is compensated for by the novel ability of this approach to contribute baseline data on how tourists will react to changes at the Athabasca Glacier site. Furthermore, the loss and degradation of resources within PAs will challenge park managers who need to balance resource conservation and visitor use mandates (Lemieux \& Eagles, 2012). The results of this research highlight the importance of identifying and understanding potential trade-offs associated with protection of the degrading resource and continued use for tourism in an era of rapid climate change. While incorporating tourists' perspectives of future landscape states in current climate adaptation planning can be complex, we have shown that engaging the public in adaptation planning is important and necessary, especially when considering different policy goals. It is therefore essential that PA managers and decision-makers invest in public engagement in climate change adaptation planning.

\section{References}

Aall, C. \& Hoyer, K.G. (2005). Tourism and climate change adaptation: The Norwegian case. In Hall, M., \& Higham, J., (Eds.), Tourism, Recreation and Climate Change (pp. 209-221). Clevedon, United Kingdom: Channel View Publications. 
Beard, J.G., \& Ragheb., M.G. (1980). Measuring leisure satisfaction. Journal of Leisure Research, 12, 20-33.

Belisario, M., Jamesk, J., Huckvale, K., O’Donoghue, J., Morrison, C.P., \& Car, J. (2015). Comparison of self-administered survey questionnaire responses collected using mobile app versus other methods. Cochrane Database of Systematic Reviews, 7, 1-113.

Briggs, S. R. \& Cheek, J. M. (1986), The role of factor analysis in the development and evaluation of personality scales. Journal of Personality, 54, 106-148.

Bushnell, R., \& McCool, S.F. (2007). Tourism as a Tool for Conservation and Support of Protected Areas: Setting the Agenda. In R. Bushnell \& P.F.J. Eagles (Eds.), Tourism and Protected Areas: Benefits Beyond Boundaries (pp. 12-26). Wallingford: $\mathrm{CAB}$ International.

Canadian Parks and Wilderness Society (CPAWS). (2015). Special CPAWS Report: Commercial development threatens Canada's national parks. Retrieved from http://cpaws.org/uploads/CPAWS-Special-Report-Commercial-Development-InParks.pdf.

Canadian Council of Resource Ministers. (2014). 2012 Canadian Nature Survey: Awareness, Participation, and Expenditures in Nature-based Recreation, Conservation, and Subsistence Activities. Ottawa: Canadian Councils of Resource Ministers.

Canadian Parks Council. (2011). The Economic Impact of Canada's National, Provincial, and Territorial Parks in 2009. Peterborough: Canadian Parks Council.

Carlsen, H., Dreborg, K. H., \& Wikman-Svahn, P. (2013). Tailor-made scenario planning for local adaptation to climate change. Mitigation and Adaptation 
Strategies for Global Change, 18(8), 1239-1255.

Clarke, G.K., Jarosch, A.H., Anslow, F.S., Radic, V., \& Menounos, B. (2015).

Projected deglaciation of Western Canada in the twenty-first century. Nature Geoscience 8, 372-377.

Cohen, S., Prayag, G., \& Moital, M. (2014). Consumer behaviour in tourism: Concepts, influences and opportunities. Current Issues in Tourism, 17(10), 872-909.

Connelly, N.A., Brown, T.L., \& Decker, D.J. (2003). Factors affecting response rates to natural resource-focused surveys: Empirical evidence of declining rates over time. Society and Natural Resources, 16, 541-547.

Convention on Biological Diversity. (2018). Canada's Sixth National Report to the United Nations Convention on Biological Diversity. Retrieved from https://www.cbd.int/doc/nr/nr-06/ca-nr-06en.pdf?fbclid=IwAR2SprZZA8kpDqZoj8x-4JjQ-VzRZOLh7ATx75zXaqvX7IYOTZzmKp_TdQ.

Csete, M., \& Szecsi, N. (2015). The role of tourism management in adaptation to climate change-a study of a European inland area with a diversified tourism supply. Journal of Sustainable Tourism, 23(3), 477-496.

Daconto, G., \& Sherpa, L. N. (2010). Applying scenario planning to park and tourism management in Sagarmatha National Park, Khumbu, Nepal. Mountain Research and Development, 30(2), 103-112.

Eisinga, R., Grotenhuis, M., \& Pelzer, T. (2013). The reliability of a two-item scale: Pearson, Cronbach, or Spearman-Brown? International Journal of Public Health, 58(4), 637-642.

Environment and Climate Change Canada. (2016). Canadian Protected Areas Status Report 2012-2015. Retrieved from https://www.canada.ca/en/environment- 
climate-change/services/wildlife-habitat/publications/protected-areas-report2012-2015.html.

Fisichelli, N.A, Schuurman, G.W., Monahan, W.B., \& Ziesler, P.S. (2015). Protected area tourism in a changing climate: will visitation at US National Parks warm up or overheat? PloS One, 10(6), 1-13.

Furunes, T., \& Mykletun, R.J. (2012). Frozen adventure at risk? A 7-year follow-up study of Norwegian glacier tourism. Scandinavian Journal of Hospitality and Tourism, 12(4), 324-348.

Garavaglia, V., Diolaiuti, G., Smiraglia, C., Pasquale, V., \& Pelfini, M. (2012).

Evaluating tourist perception of environmental changes as a contribution to managing natural resources in glacierized areas: A case study of the forni glacier (stelvio national park, italian alps). Environmental Management, 50(6), 11251138.

Gössling, S., \& Scott, D. (2012). Scenario planning for sustainable tourism: an introduction. Journal of Sustainable Tourism, 20(6), 773-778.

Gössling, S., Scott, D., Hall, C.M., Ceron, J., \& Dubois, G. (2012). Consumer behaviour and demand response of tourists to climate change. Annals of Tourism Research, 39(1), 36-58.

Groulx, M., Lemieux, C., Lewis, J., \& Brown, S. (2017). Understanding consumer behaviour and adaptation planning responses to climate-driven environmental change in Canada's parks and protected areas: A climate futurescapes approach. Journal of Environmental Planning and Management, 1-20.

Gwaltney, C.J., Shields, A.L., Shiffman, S. (2008). Equivalence of electronic and paperand pencil administration of patient- reported outcome measures: a metaanalytic review. Value in Health, 11(2), 322-33. 
Hall, C.M. (2005). Tourism: Rethinking the social science of mobility. Harlow: Pearson.

Hall, M., \& Farge, D. (2003). Modeled climate-induced glacier change in Glacier National Park, 1850-2100. BioScience, 53, 131-140.

Ham, S., \& Weiler, B. (2007). Isolating the role of on-site interpretation in a satisfying experience. Journal of Interpretation Research, 12(2), 5-24.

Hill, J., Woodland, W., \& Gough, G. (2007). Can visitor satisfaction and knowledge about tropical rainforests be enhanced through biodiversity interpretation, and does this promote a positive attitude towards ecosystem conservation? Journal of Ecotourism, 6, 75-85.

Hugenholtz, C.H., Moorman, B.J., Barlow, J., \& Wainstein, P.A. (2008). Large-scale moraine deformation at the Athabasca Glacier, Jasper National Park, Alberta, Canada. Landslides, 5(3), 251-260.

Hvenegaard, G., \& Shultis, J. (2016). Interpretation in Protected Areas. In P. Dearden, R. Rollins \& M. Needham (Eds.), Parks and protected areas in Canada: planning and management (pp. 141-169). Don Mills: Oxford University Press. Intergovernmental Panel on Climate Change. (2013). Climate change 2013: The physical science basis Working Group I contribution to the Fifth Assessment Report of the Intergovernmental Panel on Climate Change. Stocker, T.F., Qin, D., Plattner, G.K., Tignor, M., Allen, S.K., Boschung, J., Nauels, A., Xia, Y., Bex, V., \& Midgley, P.M. (eds.). Cambridge, United Kingdon: Cambridge University Press.

International Union for Conservation of Nature. (2017). 2017 Conservation Outlook: Canadian Rocky Mountain Parks. Retrieved from https://www.worldheritageoutlook.iucn.org/explore-sites/wdpaid/26689. International Union for Conservation of Nature. (2018). Protected Areas and Climate 
Change. Retrieved from https://www.iucn.org/theme/protected-areas/ourwork/protected-areas-and-climate-change.

Jones, B., \& Scott, D. (2006a). Climate change, seasonality and visitation to Canada's national parks. Journal of Recreation Administration, 24(2), 42-62.

Jones, B., \& Scott, D. (2006b). Implications of climate change for visitation to Ontario's provincial parks. Leisure, 30(1), 233-261.

Jopp, R., Mair, J., DeLacy, T. \& Fluker, M. (2015). Climate Change Adaptation: Destination Management and the Green Tourist. Tourism Planning \& Development, 12(3), 300-320.

Lemieux, C. (2016). Planning and Managing Canada's Protected Areas in an Era of Rapid Climate Change. In P. Dearden, R. Rollins \& M. Needham (Eds.), Parks and protected areas in Canada: planning and management (pp. 426 - 454). Don Mills: Oxford University Press.

Lemieux, C., \& Eagles, P.F.J. (2012). Last Chance Tourism and Canada's Protected Areas: Management, Implications and Emerging Ethical Considerations. In R.H. Lemelin, J. Dawson \& E. Stewart (Eds.), Last chance tourism: Adapting tourism opportunities in a changing world (pp.195-217). New York: Routledge.

Lemieux, C., Beechey, T., \& Gray, P. (2011a). Prospects for Canada's protected areas in an era of rapid climate change. Land Use Policy, 28(4), 928-941.

Lemieux, C., Beechey, T., Scott, D., \& Gray, P. (2011b). The state of climate change adaptation in Canada's protected areas sector. Canadian Geographer / Le Géographe Canadien, 55(3), 301-317.

Lemieux, C., Groulx, M., Bocking, S., \& Beechey, T. (2018a). Evidence-based decision-making in Canada's protected areas organizations: Implications for management effectiveness. FACETS,3(1), 392-414. 
Lemieux, C., Doherty, S., Eagles, P., Groulx, M., Hvenegaard, G., Gould, J., Nisbet, E., \& Romagosa, F. (2016). Policy and management recommendations informed by the health benefits of visitor experiences in Alberta's protected areas. Journal of Park and Recreation Administration, 34(1), 24-52.

Lemieux, C., Groulx, M., Halpenny, E., Stager, H., Dawson, J., Stewart, E., \& Hvenegaard, G. (2018b). “The End of the Ice Age?”: Disappearing World Heritage and the Climate Change Communication Imperative. Environmental Communication, 12(5), 653-671.

Luckman, B., \& Kavanagh, T. (2000). Impact of climate fluctuations on mountain environments in the Canadian Rockies. Ambio, 29(7), 371-380.

Liu, X., Yang, Z., \& Xie, T. (2006). Development and conservation of glacier tourist resources-A case study of Bogda Glacier Park. Chinese Geographical Science, 16(4), 365-370.

Manfredo, M.J., Driver, B.L., \& Tarrant, M.A. (1996). Measuring leisure motivation: A meta-analysis of the recreation experience preference scales. Journal of Leisure Research, 28(3), 188-213.

Mannell, R.C. (1999). Leisure experience and satisfaction. In E.L. Jackson \& T.L. Burton (Eds.), Leisure Studies: Prospects for the Twenty-First Century (pp. 281302). State College, PA: Venture.

Manning, R. (1999). Studies in outdoor recreation: Search and research for satisfaction Second Edition. Corvallis: Oregon State University Press.

Manning, R. (2011). Studies in outdoor recreation: Search and research for satisfaction Third Edition. Corvallis: Oregon State University Press.

McCool, S.F., \& Eagles, P.F.J. (2015). Historical, Cultural and Geographic Context. In Y.F. Leung, A. Spenceley, G. Hvenegaard \& R. Buckley (Eds.), Tourism and 
visitor management in protected areas: guidelines towards sustainability (pp. 32-50). Gland, Switzerland: IUNC.

Murdock, T.Q., Sobie, S.R., Zwiers, F.W., \& Eckstrand, H.D. (2013). Climate change and extremes in the Canadian columbian basin. Atmopshere-Ocean, 51(4), 456469.

Needham, M.D., Ceurvorst, R.L., \& Tynon, J.F. (2013). Toward an approach for measuring indicators of facility carrying capacity in outdoor recreation areas. Journal of Leisure Research, 45(3), 345-366.

Needham, M.D., Dearden, P., Rollins, R., \& McNamee, K. (2016a). Parks and Protected Areas in Canada. In P. Dearden, R. Rollins \& M. Needham (Eds.), Parks and protected areas in Canada: planning and management (pp. 3-38). Don Mills: Oxford University Press.

Needham, M.D., Haider, W., \& Rollins, R. (2016b). Protected Areas and Visitors: Theory, Planning and Management. In P. Dearden, R. Rollins \& M. Needham (Eds.), Parks and protected areas in Canada: planning and management (pp. 104-140). Don Mills: Oxford University Press.

Newsome, D., Moore, S.A., \& Dowling, R.K. (2013). Natural Area Tourism: Ecology, Impacts, and Management. Bristol, UK: Channel View.

Office of the Auditor General of Canada. (2013). Chapter 7: Ecological Integrity in National Parks. Retrieved from http://www.oag bvg.gc.ca/internet/English/parl_cesd_201311_07_e_38677.html

Page, S. J., Yeoman, I., Connell, J., \& Greenwood, C. (2010). Scenario planning as a tool to understand uncertainty in tourism: The example of transport and tourism in Scotland in 2025. Current Issues in Tourism, 13(2), 99-137.

Parks Canada. (2010). Jasper national park of Canada management plan. Retrieved 
from http://www.pc.gc.ca/eng/pn-np/ab/jasper/plan/plandirecteurmanagementplan.aspx.

Parks Canada. (2014). Jasper National Park: Columbia Icefield Area and the Athabasca Glacier. Retrieved from http://www.pc.gc.ca/eng/pn-np/ab/jasper/activ/exploreinterets/glacier-athabasca.aspx.

Parks Canada. (2016). State of Canada's National and Cultural Heritage Places.

Retrieved from https://www.pc.gc.ca/en/docs/pc/rpts/elnhc-scnhp.

Parks Canada. (2017). Jasper National Park. Retrieved from

https://www.pc.gc.ca/en/pn-

np/ab/jasper/activ/itineraires-itineraries/promenadedesglaciersicefieldsparkway/DecouvrePG-DiscoverIP.

Parks Canada. (2018a). Parks Canada Attendance 2017-18. Retrieved from https://www.pc.gc.ca/en/docs/pc/attend.

Parks Canada. (2018b). Parks Canada Visitor Information Program Survey.

Parks Canada. (2018c). The Parks Canada Mandate and Charter. Retrieved from https://www.pc.gc.ca/en/agence-agency/mandat-mandate.

Purdie, H., Gomez, C., \& Espiner, S. (2015). Glacier recession and the changing rockfall hazard: Implications for glacier tourism. New Zealand Geographer, 71, 189202.

Ramirez, R., \& Wilkinson, A. (2014). Rethinking the 2x2 scenario method: Grid or frames? Technological Forecasting \& Social Change, 86, 254.

Rollins, R., Dearden, P., \& Fennell, D. (2016). Tourism, Ecotourism, and Protected Areas. In P. Dearden, R. Rollins \& M. Needham (Eds.), Parks and protected areas in Canada: planning and management (pp. 391-425). Don Mills: Oxford University Press. 
Schweizer, S., Davis, S., \& Thompson, J.L. (2013). Changing the conversation about climate change: A theoretical framework for place-based climate change engagement. Environmental Communication: A journal of Nature and Culture, $7(1), 42-62$.

Scott, D., \& Lemieux, C. (2010). Weather and Climate Information for Tourism. Procedia Environmental Sciences, 1, 146-183.

Scott, D., Jones, B., \& Konopek, J. (2007). Implications of climate and environmental change for nature-based tourism in the Canadian Rocky Mountains: A case study of Waterton Lakes National Park. Tourism Management, 28(2), 507-579.

Scott, D., Gössling, S., \& de Freitas, C.R. (2008). Preferred climates for tourism: case studies from Canada, New Zealand and Swedan. Climate Research, 38, 61-73.

Scott, D., Gössling, S., \& Hall, C. (2012a). International tourism and climate change. Wiley Interdisciplinary Reviews: Climate Change, 3(3), 213-232.

Scott, D., Hall, C. M., \& Gössling, S. (2012b), Tourism and climate change: Impacts, adaptation and mitigation. Contemporary geographies of leisure, tourism and mobility, 10, Routledge, London, New York.

Slaughter, M. (2018). Gondola proposed to help tourists see retreating Franz Josef Glacier. Retrieved from https://www.stuff.co.nz/business/108206171/gondolaproposed-to-help-tourists-see-retreating-franz-josef-glacier.

Statistics Canada. (2016). Median total income, by family type, by province and territory. Retrieved from http://www.statcan.gc.ca/tables-tableaux/sumsom/101/cst01/famil108a-eng.htm.

Steeh, C.G., Kirgis, N., Cannon, B., \& DeWitt, J. (2001). Are they really as bad as they seem? Nonresponse rates at the end of the twentieth century. Journal of Official Statistics, 17(2), 227-247. 
Stevens, J.P. (2009). Applied multivariate statistics for the social sciences. New York, NY: Taylor \& Francis Group.

Stewart, E.J., Wilson, J., Espiner, S., Purdie, H., Lemieux, C., \& Dawson, J. (2016). Implications of climate change for glacier tourism. Tourism Geographies, 18(4), 377-398.

Tennant, C., \& Menounos, B. (2013). Glacier change of the Columbia Icefield, Canadian Rocky Mountains, 1919-2009. Journal of Glaciology, 59(216), 671686.

Tonge, J., \& Moore, S. A. (2007). Importance-satisfaction analysis for marine-park hinterlands: A Western Australian case study. Tourism Management, 28(3), 768776.

Vaske, J.J. (2008). Survey research and analysis: Applications in parks, recreation and human dimensions. State College, PA: Venture Publishing.

Wang, S., \& Jiao, S. (2012). Adaptation models of mountain glacier tourism to climate change: a case study of Mt. Yulong Snow scenic area. Sciences in Cold and Arid Regions, 4(5), 401-407.

Wang, S., He, Y., \& Song, X. (2010). Impacts of climate warming on alpine glacier tourism and adaptive measures: A case study of Baishui Glacier No. 1 in Yulong Snow Mountain, Southwestern China. Journal of Earth Science, 21(2), 166-178.

Wang, X. \& Walker, G.J. (2010). A comparison of Canadian and Chinese university students' travel motivations. Leisure, 34(3), 279-293.

Welling, J. T., Árnason, P., \& Ólafsdottír, R. (2015). Glacier tourism: A scoping review. Tourism Geographies, 17(5), 635-662.

Wilson, J., Stewart, E. J., Espiner, S., \& Purdie, H. (2014). Last chance tourism at the Franz Josef and Fox Glaciers, Westland Tai Poutini National Park: A survey of 
visitor experience (Research Report No. 33). Canterbury: Lincoln University.

Wright, P.A. (2016). Managing the National Parks. In P. Dearden, R. Rollins \& M. Needham (Eds.), Parks and protected areas in Canada: planning and management (pp. 174-212). Don Mills: Oxford University Press.

Yuan, L., Lu, A., Ning, B., \& He, Y. (2006). Impacts of Yulong Mountain glacier on tourism in Lijiang. Journal of Mountain Science, 3(1), 71-80. 